\title{
Chapter 6 \\ Governing Through Rituals: Regulatory \\ Ritualism in Czech Migration \\ and Integration Policy
}

\author{
Karel Čada and Karina Hoření
}

\subsection{Introduction}

With low unemployment levels and a large industrial sector, over the last decade the Czech Republic has faced a significant shortage in the workforce that migrants have been able to fill, and migration has begun to feature in economic debates. Despite the pressing need for foreign employees, migrants still face complicated administration, precarious working conditions and a lack of support from public bodies. Migration policy is primarily driven by the vision of short-term labour migration that is regulated according to economic needs. This does not take into account the perspective of migrants or any need for them to integrate into broader Czech society.

This chapter summarizes the current situation of labour migration in the Czech Republic, focusing on migrants from non-EU countries. We here give an overview of the policies and legal framework that govern migration based on an analysis of the governmental Strategy of Migration and the Act on Residence of Foreign Nationals in the Czech Republic. The development of these official documents is explained together with the broader social and historical context of the Czech Republic. Our overview is accompanied by a description of the integration tools established over the last decade, which represent important milestone in dealing with migration.

\footnotetext{
K. Čada $(\bowtie)$

Institute of Managerial Psychology and Sociology, Facility of Business Administration, Prague University of Economics and Business, Prague, Czech Republic

e-mail: karel.cada.kmps@vse.cz

K. Hoření $(\bowtie)$

Institute of Sociological Studies, Faculty of Social Science, Charles University (CUNI),

Prague, Czech Republic

e-mail: karina.horeni@fsv.cuni.cz
} 
This evidence is based on analysis of existing documents and statements produced on a long-term basis by various actors in the field of migration: non-governmental organisations, labour unions and employers' organisations, alongside interviews with twenty-five experts and practitioners (representatives of non-governmental organisations and public bodies).

We employ the concept of regulatory ritualism to grasp the distinctive features of the Czech system. Regulatory theorists (Braithwaite et al. 2007; Braithwaite 2008; Braithwaite 2009; Adcock 2012; Heimer and Gazley 2012; Ford 2016) use this term to describe a way of adapting to a normative order. The authors build on sociologist Robert Merton's typology of five modes of individual adaptation to cultural values: conformity, innovation, ritualism, retreatism and rebellion (Merton 1968) and on 'new institutionalism' that conceives institutions as myths or ceremonies (Meyer and Rowan 1977).

Merton (1968) argues that following the rules becomes an end in itself rather than a means to an end. Following Merton, Braithwaite (2008: 141) defines regulatory ritualism as the "acceptance of institutionalised means for securing regulatory goals while losing focus on achieving the goals or outcomes themselves". Policies, as organizations, might be conceived along a continuum with, at one end, production policies under "strong output controls" and, at the other, policies "whose success depends on the confidence and stability achieved by isomorphism with institutional rules" (Meyer and Rowan 1977: 346). Institutional means that have lost focus on their outcomes play a more ceremonial or ritual function in relation to gaining external legitimacy (Charlesworth 2017), or in relation to comforting the public and cementing the dominant normative order (Power 1997). In particular, there might be a ritual or ceremonial function to the introduction or implementation of new rules. The mechanism for introducing rules usually results from a history of institutional layering (Mahoney and Thalen 2009), in which new rules have been introduced on top of or alongside existing ones. This creates a complicated and complex regulatory framework that migrants will struggle to navigate. In relation to rules implementation, we also face classical 'bureaucratic rituals' (Cicourel 2005) or 'administrative rituals' (Samier 1997) that construct the social roles of clients and personnel.

This chapter sheds light on the causes of such institutional settings and the consequences of complex, centralized and rigid systems for migrants and their integration. What kind of normative order is produced by this institutional setting, and how is migration governed through administrative practice and institutional work? We introduce the historical and political context of migration policy, its institutional design, the Act on Residence of Foreign Nationals in the Czech Republic, the position of foreigners in Czech labour law, and at the end of the chapter we describe the contours of Czech integration policy and the consequences of such a status quo. 


\subsection{Historical and Political Context}

The Czech Republic has the lowest unemployment rate in the EU, i.e. $1.9 \%$ in August 2019 (Czech Statistical Office 2019). It is the only EU country where the unemployment rate of third country nationals is very close to that of the overall population (European Migration Network 2019). The labour market is segmented, as in other European countries. As Drbohlav (2003) argues, one of the characteristic features of the Czech labour market is that individual ethnic immigrant groups have found specific economic niches in mostly manual, low paying, low quality positions that are unattractive to the domestic labour force: Ukrainians in construction, Vietnamese in retail trade and Mongolians in manufacturing. Generally speaking, foreigners represent $13 \%$ of the workforce in construction, $6 \%$ in the manufacturing sector, and $5 \%$ in commerce (see Consortium of Non-Governmental Organisations Working with Migrants in the Czech Republic 2015). Consequently, immigrant labour plays more of a complementary than a competitive role.

During the communist regime (1948-1989), Czechoslovakia was a sending country - an estimated 200,000 citizens left - and the important migration flows were domestic. Slovaks and minorities from the Slovak part of the federation (Roma, Hungarians) moved into Czech industrial cities. Nowadays, Slovaks are the second biggest group of foreign nationals, but their status is special both in the several aspects of the legal system and the perceptions of the wider society (there is no major language or cultural difference). In terms of international migration, Czechoslovakia is historically an industrial country with a need for a workforce, and therefore, migration from other socialist countries (Yugoslavia, Cuba, Vietnam) was organised in the 1970s and 1980s. There were no specific integration efforts from the state and those workers left after the fall of communism in 1989. However, a strong current of migration from Vietnam is a legacy of networks that were established in this period. Currently, the strongest migrant flows are also from other post-socialist countries because of close cultural, language and personal bonds. These migration flows started in the early 1990s.

The number of foreigners has been growing since 1990 with a short break during the financial crisis. Especially between 2004 and 2008, the country saw a significant increase in the number of immigrants due to a favourable economic situation and labour shortages. In 2018, the total number of foreign nationals living in the Czech Republic was 552,000 , approximately $4.5 \%$ of the population. The national structure of incoming migrants is stable: the main routes are from post-socialist countries (the Ukraine, Slovakia, Russian Federation or Moldova) and from Vietnam. The biggest groups by nationality are consistently Ukrainians, Slovaks, Vietnamese and nationals of the Russian Federation, who altogether constitute around 75\% of nonEU migrants in 2018 (Czech Statistical Office). There are important streams of labour migration from other EU countries: Romania, Bulgaria and Poland. However, there is also a significant number of expats from the UK or Germany who occupy white collar jobs in big cities. 
The highest share of foreigners lives in the capital of Prague (14.5\%). Prague's migrant population is also the most diverse. The three largest non-EU migrant communities (Ukrainians, Vietnamese, Russians) comprise only half of the foreigners in Prague. The second highest share of foreigners in the population is in the Karlovy Vary region $(6.5 \%)$ and the third highest share is seen in the Plzen region $(5.1 \%)$ in the west of the Czech Republic, close to the border with Germany. Migration flows to these regions have deeper historical roots. Migrant communities from Vietnam developed their businesses through cross-border trade in the 1990s. A sizable population of foreigners, mostly males, can be found in the city of Mladá Boleslav, the seat of the Škoda car factory (Czech Statistical Office 2018a, b).

Because of relatively low numbers of migrants ${ }^{1}$ and the export-oriented economy, the domestic workforce is becoming dependent on foreign labour. The main characteristic of public debate and migration policy is the current clash between the insufficient labour force and the needs of employers on the one hand, and a general reluctance towards migrants on the other. Generally, a reluctant attitude ${ }^{2}$ could be observed in Czech society during and after the recent refugee crisis, although the number of actual refugees was very low at the time in the country (Čada, Frantová 2019).

Until the so-called refugee crisis of 2015, migration was not significantly present in political discourse, but since then anti-migration rhetoric has been shared on different scales by both far-right political parties (Dawn of Direct Democracy, later Freedom and Direct Democracy), and mainstream parties on both the left and the right proposing the securitization of migration policies. However, the Czech Republic is not an exception. The general refusal to redistribute refugees, along with a wave of anti-Muslim sentiment, are common features in all the post-socialist countries of the EU (Pachocka 2016). This demand for securitization and tighter control of migration is a significant driver for regulatory rituals. In 2018 and 2019, when the Act on The Residence of Foreign Nationals in the Czech Republic was changed for the last time and discussed in the Czech Parliament, the Members of Parliament repeatedly emphasized the need to protect Czech citizens. ${ }^{3}$

The securitization trend can be seen as a version of penal populism, "a punishment policy developed primarily for its anticipated popularity" (Roberts et al. 2003: 6) or "a political style that builds on collective sentiments of fear and demands for punitive politics" (Curato 2016: 93) which is driven by increasing popularity of

\footnotetext{
${ }^{1}$ Even though, in 2017, the number of third-country nationals holding a valid permit was the highest among post-socialist Central European states. In the Czech Republic, there were 26 valid permits per 1000 people in the total population. There were nine in Slovakia, six in Hungary and 16 in Poland. However, in Germany, there were 56 valid permits per 1000 inhabitants (see European Migration Network 2019).

${ }^{2}$ According to a poll organised by the Public Opinion Research Center in April 2019, 53\% of the Czech population thinks that 'incoming foreigners' represent a problem for the Czech Republic (Public Opinion Research Center 2019).

${ }^{3}$ Parliamentary Discussions in 19the September 2018, 7th December 2018 and 13th March 2019 (see http://www.psp.cz/sqw/historie.sqw?T=203\&O=8 - Accessed 7the November 2019).
} 
populist radical right-wing parties and the tabloid media (see Boda and his colleagues 2015). The extension of rules intended for tight control over migration might be seen as a response to fear discourses that portray migrants as a danger for domestic societies.

\subsection{Migration Policy}

The Czech migration policy is highly centralized with the Ministry of Interior being a crucial actor. The Ministry is responsible for both migration regulation and integration policy. This is a result of a change in 2008 that moved the responsibility for integration policy from the Ministry of Labour and Social Affairs to the Ministry of the Interior. In the economic boom between 2004 and 2008, the Ministry of the Interior was responsible for asylum policy, visa and residence permits, and the Ministry of Labour and Social affair for integrating foreigners. However, in the aftermath of economic crisis, both streams of policy were integrated into the Ministry of the Interior.

This high level of centralization is not only typical for migration policy in the Czech Republic. The proportional electoral system tends towards a coalition government with strong ministries but a weak prime ministerial cabinet, so cross-section issues like migration, social inclusion or drug policy are seized by one ministry at expense of the others. The position of the Ministry of the Interior in the Czech migration policy partly stems from the restrictive tendencies towards migration in the Czech policy discourse but also from the Czech governmental tradition, which is marked by strong departmentalization and a lack of coordination in government.

Switching between liberal and restrictive tendencies has been symptomatic of the development of the Czech migration policy framework since 1989. Bauerová (2018), with a reference to Baršová and Barša (2005), distinguishes six periods of the Czech integration policy: (1) the laissez faire period (1990-1995) with relatively liberal conditions of entry, but an absence of tools for the integration of immigrants; (2) the restrictive period (1996-1999): the conditions of entry were tightening due to the economic crisis and fears of increasing numbers of immigrants from western Balkan and post-Soviet states; (3) the EU accession period (1999-2004), in which a complex migration policy was formulated ${ }^{4}$; (4) the neoliberal period (2005-2008), in which the state formulated a long-term framework for the integration of foreigners, however, this contained only a vague call for cooperation to be developed at the local level; (5) the neo-restrictive period (2008-2014), in which the Czech Republic introduced a more restrictive policy to reduce the numbers of foreigners because of the economic crisis and to deal with corruption problems at embassies in Ukraine or

\footnotetext{
${ }^{4}$ This was reflected in two documents: (1) Principles of Integration of Foreigners in the Czech Republic and (2) The Conception of Integration of Foreigners in the CR, which "promotes the integration of foreigners as individuals" (Baršová and Barša 2005, pp. 233-236).
} 
Vietnam $^{5}$; (6) the migration crisis period (since 2015), when the Czech Republic actively negotiated with the European Commission and the Czech Republic refused to accept a quota system.

Different migration policies are also reflected in the numbers of foreigners. These numbers culminated during the neo-liberal period, so more than 45,000 incoming MRAs in 2008 (Czech Statistical Office 2019), and they later stagnated during the restrictive phase after the economic crisis (8177 in 2010). In the last period, the numbers have increased again (more than 30,000 incoming MRAs in 2018), despite the restrictive frame of migration regulation that has prevailed. The increase can be assigned to the labour shortage and the economic boom.

Czech migration policy is marked by the coexistence of national and European levels, which has created somewhat schizophrenic conditions. On one hand, efforts have been made to introduce more restrictive conditions of entry and stay, while on the other, Czech migration policy must comply with EU regulation that strengthens civil rights and supports permanent settlement (Kušniráková 2014).

In the most recent period, the main document that states the goals of the government is the Strategy of Migration Policy (Czech Government 2015). The Strategy, proposed by the Ministry of the Interior, strengthens the security aspects and emphasizes that migration should be regulated or even prevented with development aid. The particular situation of economic migrants is reflected only in the final goal, while labour migration is treated pragmatically and only from the perspective of the needs of the labour market.

\subsection{Legislation Governing Migration}

The Constitution of the Czech Republic should ensure basic rights to all citizens and migrants with regular status, and it incorporates the Charter of Fundamental Rights and Freedoms as a component of the constitutional order. ${ }^{6}$ The main document that guides regulation of stay for different groups of foreigners is Act No. 326/1999

\footnotetext{
${ }^{5}$ The Government Resolution No. 1205/2009 of 16 September 2009 limited foreigners' options to apply for a long-term visa (in excess of 90 days), the amendment to Act No. 326/1999 Coll., on the Stay of Foreigners in the Czech Republic tightened conditions for foreigners, who had to indicate the purpose of their business as the reason for their stay, there was a change in the conditions of travel health insurance for foreigners and the introduction of biometric ID cards for foreigners (see Bauerová 2018).

${ }^{6}$ The Charter includes, among other important rights, guarantees of citizens' economic, social and cultural rights. Among these are the right to the free choice of occupation (Article 26/1), the right to acquire the means of one's livelihood by work (Article 26/3), the right of employees to fair remuneration for work and satisfactory working conditions (Article 28/3), the right of women, young persons and persons with disabilities to increased safety and health at work, including special working conditions and assistance in vocational training (Article 29), the right to freely associate with others with a view to protecting economic and social interests (Article 27/1), or the right to strike (Article 27/4).
} 
Coll., the Act on Residence of Foreign Nationals in the Czech Republic, and by Act No. 325/1999 Coll., on Asylum.

In the context of the Act on Residence of Foreign Nationals in the Czech Republic, one can distinguish four categories of permit: (1) short-term visas (for stays of up to 90 days); (2) long-term visas (for stays of over 90 days); (3) long-term residence (for the purpose of doing business, an employee card, for the purpose of a family living together in the Czech Republic); and (4) permanent residence. Short-term visas are valid for one or more entries, they give the right to stay in the Schengen area for the period indicated in them. The length of continuous residence or the total length of successive stays in the Schengen area must not exceed 90 days within any 180-day period. In terms of a long-term visa, the Czech law distinguishes long-term visas for the purposes of a business, family reunification, studies, exceptional leave to remain and other (Section 42 of Act 326). The foreigner must apply for a long-term visa 14 days before his or her visa expires, at the latest. The Ministry is very restrictive and, with the exception of serious health problems or a proven impossibility of contacting the public administration, the Ministry does not accept applications lodged after the deadline (Koldinská et al. 2015).

Long-term residence for business purposes can be applied for if a foreigner is a self-employed person in the Czech Republic, a statutory authority (executive director, manager) or a member of the statutory bodies of a company or cooperative. With respect to long-term residence for the purpose of family reunification, MRAs face a number of obstacles to the realization of their right to family life, such as unreasonably long deadlines for processing their application and poor information about processing their applications (Organization for Aid to Refugees 2016).

A renewal application for a long-term residence permit (over 90 days) can be submitted only between the 120th and the 14th day before the expiry of such a permit. The Ministry is also highly restrictive in this issue. The recent practice is criticized by Czech NGOs: "The current arrangement is an unnecessary impediment in terms of the costs of such procedures" the NGOs wrote in their manifesto (Consortium of Non-Governmental Organisations Working with Migrants in the Czech Republic 2015).

Permanent residence (Section 63 Act 326) can be applied for after five years of uninterrupted temporary stay in the territory of the Czech Republic. Without compliance with the condition of five years of uninterrupted temporary stay, permanent residence can still be applied for under certain exceptions, e.g. for humanitarian reasons, for reasons deserving special consideration, in some cases following the conclusion of proceedings on international protection, etc. The application can be submitted at a branch of the Ministry of the Interior, or in some cases at a Czech embassy. The foreigner must pass Czech language exams (A1 level). Foreigners with permanent residence have very limited legal possibilities for political participation. They cannot vote in local elections. They cannot establish political parties and cannot be members of established parties.

In terms of refugees and asylum seekers, administrative proceedings for granting international protection are held by the Ministry of the Interior (Act No 325/1999 Coll., on Asylum). These proceedings are launched by the foreigner's declaration 
that he or she is willing to apply for international protection. The asylum seeker is obligated to appear at a reception centre within twenty-four hours after the declaration, and there he or she files an application for international protection and the Foreign Police performs identification processes. The asylum seeker is also required to undergo a medical examination. The Ministry may detain the applicant at the reception centre for up to 120 days if his or her identity has not been verified (he or she does not have a valid travel document, or the identity document is falsified) or there is a danger to state security, public health or public order.

During the application for international protection, the reasons that led refugees to depart from the country where he or she was staying are determined. When the required tasks are completed, the applicant is transferred to a reception centre, where he or she awaits the first instance decision. The Ministry grants asylum according to the Geneva convention to the applicant, if it is proved that the foreigner was persecuted for the exercise of political rights and freedoms or has a justified fear of persecution on the basis of race, gender, religion, nationality, membership in a particular social group or certain political views in the state of which he or she is a national or, if he/she is a stateless person, in the state of his/her last permanent residence. Over the course of this period, an interview is conducted with the applicant, which is intended to verify the reasons for international protection that were stated in the application.

The Ministry issues a decision within six months. If a decision cannot be made within this timeframe due to the specific nature of the matter, the Ministry can extend it appropriately, up to 18 months, the maximum allowed by EU regulation. As the Consortium of Migrants Assisting Non-Governmental Organizations (2015) points out, undocumented refugees routinely wait up to 120 days in special detention facilities, which house families with children, traumatised people, and torture victims. In addition to detention, undocumented refugees are added to a database to prevent them from applying for any form of visa in the Czech Republic or the EU.

The Act on Residence of Foreign Nationals in the Czech Republic has been incrementally changed many times. As Čižinský and his colleagues (2014) note, due to numerous amendments, the Act on Residence of Foreign Nationals in the Czech Republic has become an unclear and chaotic piece of legislation. For example, between 2017 and 2019, the Parliament passed two extensive amendments and the Constitutional Court cancelled a number of provisions of the first one. ${ }^{7}$ Layering new rules on top of old rules seems to be common practice in the Czech policy. In the Czech system, Members of Parliament have rights to legislative initiative - they are allowed both to propose amendments to government bills and to propose their own bills. The legislative process combined with the multiple party proportional system and fragile government coalitions create a chaotic and unpredictable legislative environment.

\footnotetext{
${ }^{7}$ See the Judgment $41 / 17$ in which the Constitutional Court cancelled the number of provisions of the act because they do not comply with the EU law or Czech constitutional principles.
} 
These problems can be illustrated by the story of the last two amendments of the Act on Residence of Foreign Nationals. Both amendments were justified by the need to adapt the EU directives into Czech law. The first concerned Directive 2014/66/EU and the second Directive 2016/801/EU. However, in both cases the transposition of European law was used to tighten residency rules beyond the scope of the original directives. In the first case, the transposition of the EU directive introduced a special type of permit for foreign investors and seasonal workers; however, the amendment also limited possibilities for transition to a business residence, it made it more difficult to change employer or request permanent residence. In the second amendment, which passed in 2019, the transposition of the EU directive should significantly improve the situation of university students and scientific personnel who, after they finish their studies or scientific work, will be allowed to stay in the Czech Republic for a period of up to nine months to search for employment or commence business activities.

Besides this transposition, the amendment introduces the duty of non-EU foreigners to attend an eight-hour adaptation and integration course within one year of the date they receive their permanent or long-term residency permit, and the possibility for government to introduce quotas of permits for specific countries of origin, sectors of the Czech economy and types of work. The amendment also introduces into Czech law a model of temporary labour migration (Gastarbeiter), in which foreigners are able to come to the country for only one year, then leave and arrange a new visa again abroad. This model thus reduces foreigners to a mere labour force, explicitly excluding foreigners from integrating into the Czech Republic. As critics of the amendment point out (Consortium of Non-Governmental Organisations Working with Migrants in the Czech Republic 2018), experiences of countries such as Germany (which applied the model in 50s and 60s) prove that a significant portion of seasonal workers settled down in the new country and lived there, but without sufficient integrational support.

Instead of comprehensive change based on dialogue among governmental actors, public authorities, employers, NGOs and representatives of migrants, The Act on Residence of Foreign Nationals in the Czech Republic has been being changed piecemeal without any clear implementation plan. The compulsory adaptation and integration courses can easily illustrate this feature of Czech policy-making. There is no guarantee the state will be able to build the necessary infrastructure to run the adaptation and integration courses compulsory from 2020. The amendment lists selected groups of foreigners who are exempted from this duty. However, it does not deal with individuals who cannot complete the course because of language, physical disability or, indeed, lack of available courses.

With respect to the anti-migration discourse, the tightening of rules driven by the need to protect domestic citizens might be interpreted as a 'ritual of comfort' (Power 1997) in a situation where Czech public and political elites are aware of the negative consequences of migration. Tightening rules serves a ceremonial function by claiming boundaries between Czech citizens and migrants. Through the implementation of new rules, politicians and policymakers prove they act in the name of citizens. However, such a ritualistic character is mostly rooted in the idea that migration can 
be governed by the rules alone, without complex policies of rule enforcement, implementation and institution-building. There are rules proposed without clear evidence, such as in the case of the model of temporary labour migration, or without a clear implementation plan, such as in the case of compulsory integration courses. The large number and complexity of rules does not improve migrant selection, however, it does drive inconsistency in how standards are enforced. Moreover, a proliferation of more specific laws is a resource that expands discretion, rather than limits it (Baldwin and Hawkins 1984).

The experiences of migrants can substantiate such uncertainty and arbitrariness in administrative decisions. Elena Tulupova, a Russian scientist living in the Czech Republic, summarizes her experience with the Czech system in this way: "Public officers do not manage to deal with requests in a timely manner and cases last for several years and decisions are questionable" (Rahimi 2017).

Czech migration policy seems locked in a mutual circle of suspicion. The administrative bodies look at migrants through lenses of suspicion, while migrants through lenses of suspicion interpret administrative decisions. These circles of suspicion broaden barriers between migrants and the state. They significantly decrease the level of trust between migrants, administrative bodies and, in the end, the rest of the society. But institutional trust is key currency in integrational policies.

\subsection{Labour Market Integration}

The access of third-country nationals to the labour market is regulated both by the Labor Office of the Czech Republic and the Ministry of the Interior of the Czech Republic. Work permits may be issued in various forms, such as: (1) an Employee Card (dual or non-dual); (2) a Blue Card (for highly qualified professions); or a (3) permit to work issued for a previously authorized stay (usually for other purposes such as business, family reunion, study, etc.) or to seasonal work up to six months.

The Employee Card works as a permit for a long-term residence, granting the foreigner temporary residence in the territory for a period exceeding three months and allowing work performance in the position for which the Employee Card was issued. The Employee Card can be either dual (combining a work-permit and a residence permit) or single-purpose (it grants the foreigner only residence in the territory). The dual Employee Card is issued by the Ministry of the Interior for a specific job position, which is listed by the Ministry of Labour and Social Affairs in the central register of vacancies occupied by employee cardholders (a job that has not been filled within 30 days of its notification to the regional branch of the Labour Office). If the job position is listed and cannot be filled by the domestic labour force, the labour office is obliged to issue a work permit. Then, the foreigner must demonstrate his or her professional competence. In justified cases, especially when there is reasonable doubt whether the foreigner has the required education or whether this education corresponds to the character of the job, the foreigner is obliged to 
prove - upon request of the Ministry of the Interior - that his/her education was recognized as equivalent by a competent authority of the Czech Republic.

A non-EU migrant may apply for the single-purpose Employee Card if he or she wants to stay in the territory of the Czech Republic for more than three months for the purpose of employment and he or she is: (1) a foreign national who is obliged to apply for an employment permit; or (2) a foreign national with free access to the labour market. In such cases, the job position in question is not listed in the Central Register of Job Vacancies and the Ministry of the Interior does not look into the professional competence of the applicant: it is monitored either by the labour office as a part of the procedure for granting an employment permit, or it is up to the employer to decide whether or not it is required.

For both types of card, it is required that a form of labour-law relationship exists between the foreigner and the employer, which the applicant must prove by submitting an employment contract, an agreement to perform work or a letter of intent. In all cases, the weekly working hours must amount to at least 15 hours and the monthly wage, salary or remuneration may not be lower than the basic monthly rate of the minimum wage.

A job vacancy, which can be filled under the Blue Card regime, means such vacancy that has not been filled within 30 days since it was reported to the regional labour office and for performance of which a high qualification is required - i.e. regularly completed higher education or higher professional education provided that the study lasted for at least three years.

An employment permit has to be applied for at the regional branch of the Labour Office within whose remit one plans to work. The employer must announce the intention to employ a migrant to the regional office of the labour office. The office will carry out the so-called labour market test to assess the demand of employers for the given profession in the given region and the probability of its satisfaction by Czech workers or EU citizens.

An employment permit is valid only for a specific employer (who is mentioned in the decision) and for a specific type and place of employment (if one plans to work for one employer on two job positions, then one needs an individual employment permit for each job; if one wants to perform the same job position for another employer, then one must obtain a new employment permit as well). An employment permit is non-transferable (another person cannot make use of it) and it is issued for a fixed period of time, two years maximum. An employment permit can be applied for repeatedly.

A work permit, Employee Card or Blue Card is not required for the employment of a foreigner with a permanent residence permit, a foreigner who has been granted asylum, a foreigner whose work in the Czech Republic does not exceed seven calendar days or a total of 30 days in a calendar year or a foreigner who is a performer, scientist, student under 26 years of age, an athlete or a person who supplies goods or services in the Czech Republic on the basis of a commercial contract, or performs warranty and repair work. Foreigners can also do business in the Czech Republic in the same way as Czech citizens without any limits. The number of foreigners holding a trade licence has been gradually increasing year by year. At the end of 2017, 
there were 472,354 registered with the Employee Cards, Blue Cards or permits to work and 87,228 holding a valid trade licence. Among those registered at labour office, there were 142,200 third-country nationals. Among them, 101,48 did not need a work permit, 15,162 holding a valid work permit, 24,753 Employee Cards and 413 Blue Cards. A total of 55,439 third-countries nationals had a valid trade licence. The vast majority comes from Vietnam $(21,773)$ and the Ukraine $(21,746)$ (Czech Statistical Office 2018b).

The rules governing the issuing work permits have changed in different periods of migration policies. In 2010 as a part of restrictive migration policy after the financial crisis, for example, labour offices were asked to act more strictly in issuing employment permits to foreigners:

They were asked not to issue employment permits to foreigners for such job positions that can be filled by persons with free admission to the Czech labour market. The length of the stay or the level of integration of individual foreigners was completely disregarded. (Čižinský et al. 2014:47)

The attempts to make work permits more restrictive continued in 2012 when granting employment permits to low-qualified positions was heavily discussed among politicians and employer organisations. A fundamental change came into effect in June 2014. The reason for the amendment was to implement Directive 2011/98/EU of the European Parliament and of the Council of 13 December 2011 on a single application procedure for a single permit for third-country nationals to reside and work in the territory of a Member State and on a common set of rights for third-country workers legally residing in a Member State.

In the last decade, labour migration was influenced by the establishment of several nation-specific migration programmes. These were promoted mainly by the Ministry of Trade and supported by employers' associations, such as the Czech Chamber of Business. Due to these programmes, registered employers can more easily hire workers from countries such as the Ukraine, Mongolia, the Philippines and Serbia. Specific programmes to hire highly skilled workers were also established, such as The Programme India, but its quotas were never filled and the programmes to hire workers for unskilled positions were always more successful.

In the last amendment of the Act on Residence of Foreign Nationals in the Czech Republic, these specific programmers were re-formed into three main programmes. The programmes 'Highly-qualified employer' and 'Key and Research Personnel' are open to all countries. The Programme 'Middle or Low Qualified Employer' is open to nine countries (Belarus, Montenegro, the Philippines, India, Kazakhstan, Mongolia, Moldavia, Serbia, the Ukraine). The government will settle migration quotas for these countries. Other than these, the 'Extraordinary Labour Visa' was introduced, which can be activated in the case of a lack of workforce in a certain segment of the economy. Visa programmes for low-skilled professions are short-term, there are limits if the holder wants to bring their family to the country and limits to its prolongation. These recent changes are in accordance with the Strategy of Migration, with its vision of circular and short-term labour migration. 
In practice, the quotas in programmes for specific countries have been quickly filled quickly. Especially Ukrainian embassies are notoriously well known for long waiting periods, and in the past also for illegal practices for obtaining a slot to apply for the visa.

A time-consuming, rigid and unreliable system of hiring third-country nationals has led to an increasing number of irregular workers. The year 2017 saw a total of 2151 foreign citizens performing irregular work (1530 in 2016), of whom 234 were EU nationals (193 EU nationals in 2016) and 1917 third-country nationals (1337 third-country nationals in 2016) (Czech Statistical Office 2018b). Milena Jabůrková, vice president of the Confederation of Industry of the Czech Republic, comments: "The lack of workers is critical. Some companies opt for the employment of foreigners without the necessary documents" in Czech media (Zelenka and Štěpánek 2018).

Companies also avoid this dilemma by subcontracting a workforce from employment agencies. Subcontracting represents a significant factor that contributes to the labour exploitation of migrants (see Čaněk et al. 2016). Agency employees are often disadvantaged compared to other employees regarding fixed-term contracts. Many of the workers work without a contract, sign a contract they do not understand, or are given an Agreement to Complete a Job, which legally allows them to work for only 300 hours per year per employer and forces them to pay medical insurance on their own.

Labour unions characterise the current situation:

For the Czech-Moravian Confederation of Labour Unions, the employment of foreigners who are lured to the Czech Republic and have wages that are on the poverty level is unacceptable. The Czech Republic can't work against social dumping and support it at the same time. (Czech-Moravian Confederation of Trade Unions 2017)

However, this position is mostly supported by economic arguments rather than paying attention to the situation of migrants:

Unregulated labour migration is a dangerous factor leading to destabilisation of the labour market, social dumping and the end of rising wages. (Ibid.)

Labour unions do not support the change in the situation of foreign workers but use critical descriptions of the situation to oppose the growth of migration: The Czech Confederation of Labour Unions will oppose attempts to broaden the influx of cheap work labour from the third-party countries to the Czech Republic. We will support maximal usage of the inner workforce (Svoboda 2015).

Widespread praxis is to use agency employment workers. These workers are recruited by private agencies rather than by employers themselves and their working contracts often do not cover overtime hours or secure their wages. A strict set of regulations on these agencies is recommended by the Confederation of Labour Unions. On the other side are employers organisations who prefer flexible conditions in labour contracts.

The precarity of foreign workers is further multiplied by the limited social rights foreign workers enjoy compared to Czech citizens. Third-country migrants living and working in the Czech Republic but without permanent residence are obligated, 
in the same way as Czech citizens, to contribute to the social security system and the state employment policy, however, they cannot use unemployment benefits and they have only limited amount of social benefits. Furthermore, if they lose their job, they will be at risk of having their permanent residency revoked. Non-EU migrants who are not employed by a Czech company are excluded from the public health insurance system, and therefore must opt for commercial insurance which does not guarantee the same level of coverage as public health insurance (see The Consortium of Non-Governmental Organisations Working with Migrants in the Czech Republic 2015).

It seems that the regulatory ritualism of Czech migration law is creating a situation that is not favourable either for employers or for employees because it slows down the process of issuing of work permits and makes the process more insecure. Both by foreigners and by employers, the administrative process is perceived as very difficult. Especially the whole length of issuing of work permit and strict process of extending those permits. (Multicultural Centre Prague 2013).

If the focus of regulation is supposed to be the protection and stabilization of the labour market, the recent regulation framework does not work well.

Instead of clear, well-founded and lawful conditions, the migration is regulated rather by processual obstructions and administrative barriers. (Consortium of Migrants Assisting Organisations in the Czech Republic 2015)

Public authorities often provide unreliable and incomprehensible information. Information provided by different staff members from the same institution can differ, while foreigners are forced to deliver new documents and repeatedly visit these offices. According to interviews conducted with members of the two largest migrant communities (Vietnamese and Ukrainian communities) in the framework of SIRIUS research, this lack of support creates a space for commercial companies to offer their guidance services, which are sometimes connected with semi-legal practices (such as re-selling time slots for visa applications or selling bank account statements) and which could lead to the exploitation of foreign workers.

With actual labour shortage, when Czech companies need to fulfil more than half-million vacant jobs (Czech Chamber of Commerce 2018), the labour market tests carried by the Labour Offices seem to be another example of regulatory rituals. However, through these rituals, the dominant normative framework of securitization and protection of domestic workforce is reinforced. In contrast to the strict administrative scrutiny of work permits, the conditions in which foreign workers are employed is loosely monitored and protection of foreign workers is significantly weaker than their Czech counterparts.

\subsection{Integration Policy and Barriers to Integration}

The main vehicle of integration policy in the Czech Republic is the network of regional Centres to Support the Integration of Foreigners. These centres, initiated by the Ministry of the Interior, are operated on the basis of projects and partially funded 
from the European Fund for the Integration of Third-country Nationals (EIF) from 2009 to 2015, and the European Asylum, Migration and Integration Fund (AMIF) starting from 2015. From July 2016 to June 2019, such centres have been operating in all of the Czech regions under individual projects. Nine are funded by the Asylum, Migration and Integration Fund (AMIF), whereas four are operated by NGOs or regional governments and only co-financed from this fund. The task of each centre is to ensure the formation of regional counselling platforms to address the current problems of foreign nationals.

In each region, the Centre mainly cooperates with the regional government and municipalities, the Foreign Police, state and municipal police, labour offices, tax authorities, trade licence offices and other entities. The goal is to create opportunities for improved information exchange and to stimulate measures to respond to the current demand of issues related to the integration of foreign nationals. All services are free of charge. They are not limited to the city where each centre is established and should cover the entire region. The centres offer: (1) social counselling; (2) legal advice (by external providers); (3) Czech language courses; (4) translation and interpreting services (mostly by Vietnamese, Mongolian, Ukrainian and Russian interpreters); (5) socio-cultural courses (fostering orientation mainly in the social security, health and educational systems); (6) an internet point and library; and (7) community outreach.

The Ministry of the Interior has also initiated the implementation of municipality projects. Funded predominantly from its subsidies, these projects are implemented by local governments, particularly in municipalities with significant numbers of foreign nationals in direct collaboration with those foreign nationals living in the municipality, with non-governmental organisations, schools and other local integration actors. The projects aim to provide comprehensive support for integration at the local level, to prevent the potential risk of - or to mitigate the tension between foreign nationals and other inhabitants of the municipalities as well as to prevent the risk of residential segregation. The Ministry has supported municipal projects in Pilsen, Pardubice, Havlíčkův Brod (where extremist actions had occurred, such as burning the Mongolian flag and the dissemination of hate leaflets), or in Prague's district of Libuš (where the biggest Vietnamese open market, 'SAPA', is located).

The Ministry of the Interior also finances NGOs that focus on integrating foreigners through specific programmes. The non-governmental sector is an important and vocal player in the field of integration because, until the establishment of integration centres, all services were provided by non-governmental organisations. Until now, regional integration centres were unable fulfil the demand for services. Other than financing from the Ministry of Interior, NGOs are also dominantly financed by the Ministry of Social Affairs or municipalities. Therefore, NGOs are fulfilling governmental or local strategies of integration.

Even though Centres to Support the Integration of Foreigners represent an important hub for integration policies, these policies face numerous obstacles as the local level. Local authorities are active only when there are serious problems that require a change in the situation between the majority society and foreigners. The absence of local integration strategies means local authorities are unprepared for such 
situations and they cannot effectively prevent them. Local municipalities also do not map the needs of foreigners on their territory to ensure adequate availability of services, including language courses, social and legal counselling.

The main challenge for integration is a lack of knowledge of the Czech language. This problem is identified by almost all actors when evaluating the level of education of both adult and young migrants and the support of teachers. Lack of language knowledge prevents migrants who work in low-skilled positions from applying for high-skilled jobs. In research interviews, stories of refugees and migrants provide evidence about problems finding a job. Stakeholders mainly report that courses have insufficient capacity and inappropriate structure.

Existing subsidized and therefore affordable language courses cannot meet the demand and are often not available in smaller cities. There are not enough advanced or specialised courses (for technical or health professionals), which prevents educated migrants from using their skills in more specialised positions.

Young migrants who attend Czech schools have a higher chance of learning the language but also face important obstacles. Notwithstanding the importance of the education system for integration processes, until now schools and teachers have lacked both experience and support in the integration of foreigners. Schools can apply for funding from the Ministry of Education, but the application process takes place prior to the start of the school year when they do not yet know whether they will be taking students with a foreign background. Furthermore, they receive the funding too late during the school year and the filing process is complicated. All these factors contribute to the low number of applications for funding from schools. Funding from the Ministry of Education is also not available to secondary schools.

Bigger cities with a higher share of foreigners have schools that specialise in the integration of students with a foreign background, and students might concentrate here. Educational experts interviewed for the SIRIUS research point out that there is a growing number of students with a foreign background who either will not be accepted into secondary school or will not be able to graduate due to poor language knowledge.

\subsection{Conclusion}

The specific legal history of the Czech Republic has created a complicated and complex regulatory framework, dominated by regulatory ritualism. The dominant frame of migration policy results from the institutional design where the Ministry of Interior is a central player. Many related agendas fall within the remit of other ministries, in particular the Ministry of Labour and Social Affairs of the Ministry of Education, Youth and Sports. However, these ministries often do not perceive foreigners as their target group, which leads to shortcomings in public policies and a lack of necessary funding. Excessive centralization has led to the low engagement of local authorities, local communities and civil society (The Consortium of Non-Governmental Organisations Working with Migrants in the Czech Republic 2015). 
Migration policy is driven by a vision of primarily short-term labour migration regulated according to economic needs. The services offered by public integration centres are not available everywhere and for all groups of migrants. The absence of integration services for EU citizens who face the same challenges as non-EU migrants (lack of language knowledge and poor orientation in the Czech legislation) is particularly striking. Integration services depend heavily on the availability of EU funding, and their future is therefore uncertain. These integration tools are not underpinned by a broader vision of integration, while the integration programmes provided by municipalities and schools are not universal and depend on the will of local political representation or principals, which might be influenced by the attitudes of parents and their voters.

The unwillingness of Czech political authorities to offer stronger structural solutions is linked to the general reluctance of the Czech population when it comes to migrants. We saw this erupt particularly during the period of the migrant crisis. Therefore, no major political party considers integration a priority. In the context of weak broader societal integration of foreigners, labour market integration policies have barely materialised and remain unimplemented. Due to the absence of any systematic and structural approach towards integration into the labour market, any progress in labour market integration policies will, therefore, be made in small steps, individual efforts and short-term solutions in the future. It is expected that these steps will be driven not only by the involvement of public authorities but also by other actors, primarily from the non-governmental sphere.

The regulatory ritualism that results from chaotic and unsystematic legislative work is characterized by a loss of focus on achieving goals and the outcomes themselves. This is especially visible in Czech migration policy, whose complex and unpredictable administrative system prompts migrants to use the services of problematic intermediaries. The time-consuming procedures that regulate getting work permits strengthen the illegal job market and the opaque system of subcontracting instead of protecting the domestic workforce and stabilizing the labour market. Furthermore, regulatory ritualism establishes a climate of mutual distrust among those actors involved and places obstacles to collaboration between public authorities, non-governmental organizations and the migrants themselves.

As Braithwaite (2008) notes, the defeat of ritualism requires networking between all the leading stakeholders and critics into a macro-project of transforming ritualism. However, this transformation through networked governance is conditioned by acuity in grasping micro-macro linkages. To transcend ritualism means changing both how policy is formulated and how policy is implemented, establishing a dialogue and mutual learning between different levels of regulation. However, this seems a difficult task in the environment of mistrust and long-lasting conflicts among involved actors in populist times. 


\section{References}

Adcock, F. (2012). The UN Special Rapporteur on the rights of indigenous peoples and New Zealand: A study in compliance ritualism. New Zealand Yearbook of International Law, $10,97-120$.

Baldwin, R., \& Hawkins, K. (1984). Discretionary justice: Davis reconsidered. Public Law, 1984, 570-599.

Baršová, A., \& Barša, P. (2005). Přistěhovalectví a liberální stát. Brno: Masarykova univerzita.

Bauerová, H. (2018). The Czech Republic and the reality of migrant integration policy in the context of European integration. Croatian and Comparative Public Administration, 18(3), 397-420.

Boda, Z., Szabó, G., Bartha, A., Medve-Bálint, G., \& Vidra, Z. (2015). Politically driven: Mapping political and media discourses of penal populism-The Hungarian case. East European Politics and Societies, 29(4), 871-891.

Braithwaite, J. (2008). Regulatory capitalism: How it works, ideas for making it work better. Cheltenham/Northampton: Edward Elgar.

Braithwaite, V. (2009). Defiance in taxation and governance. Cheltenham/Northampton: Edward Elgar.

Braithwaite, J., Makkai, T., \& Braithwaite, V. (2007). Regulating aged care: Ritualism and the new pyramid. Cheltenham/Northampton: Edward Elgar.

Čada, K., \& Frantová, V. (2019). Countering Islamophobia in the Czech Republic. In I. Law, A. Easat-Daas, A. Merali, \& S. Sayyid (Eds.), Countering Islamophobia in Europe (pp. 153-182). Cham: Palgrave Macmillan.

Čaněk, M., Qubaiová, A, KuČera, P., Voslář, V., Avramioti, I., Janků, L., Čižinský, P., \& Lupačová, H. (2016). Subcontracting and EU mobile workers in the Czech Republic: Exploitation, liability, and institutional gaps (Labcit Country Report). https://migrationonline.cz/czech_republic_country_report.pdf. Accessed 8 Aug 2019.

Charlesworth, H. (2017). A regulatory perspective on the international human rights system. In P. Drahos (Ed.), Regulatory theory: Foundations and application (pp. 357-373). Canberra: Australian National University (ANU) Press.

Cicourel, A. (2005). Bureaucratic rituals in health care delivery. Journal of Applied Linguistics and Professional Practice, 2(3), 357-370.

Čižinský, P., Čech Valentová, E., HradeČná, P., Holíková, K., Jelínková, M., Rozumek, M., \& Rozumková, P. (2014). Foreign workers in the labour market in the Czech Republic and in selected European countries. Association for Integration and Migration, Organization for Aid to Refugees, Multicultural Centre Prague. https://www.migrace.com/docs/141115_simizamestnanci-en-nahled.pdf. Accessed 8 Aug 2019.

Consortium of Migrants Assisting Organisations in the Czech Republic. (2015). Migration manifesto: Suggestions to the strategy of migration policy of the Czech Republic. http://www. migracnimanifest.cz/en/index.html. Accessed 8 Aug 2019.

Consortium of Migrants Assisting Organisations in the Czech Republic. (2018). Právní analýza vládního návrhu novely zákona o pobytu cizincủ 2018. http://www.migracnikonsorcium.cz/ wp-content/uploads/2018/10/Novela-ZPC-2018_-právn\%C3\%AD-analýza_FINAL.pdf. Accessed 8 Aug 2019.

Curato, N. (2016). Politics of anxiety, politics of hope: Penal populism and Duterte's rise to power. Journal of Current Southeast Asian Affairs, 35(3), 91-109.

Czech Chamber of Commerce. (2018). Dlouhý: Zaměstnavatelé reálně postrádaji 440 tisíc lidí. https://www.komora.cz/press_release/dlouhy-zamestnavatele-realne-postradaji-440-tisiclidi-ztraty-na-danich-a-odvodech-v-roce-2019-presahnou-110-miliard-korun/. Accessed 30 Oct 2019. 
Czech Government. (2015). Migration policy strategy of the Czech Republic. https://www.mvcr.cz/ migrace/soubor/migration-policy-strategy-of-the-czech-republic.aspx. Accessed 8 Aug 2019.

Czech Statistical Office. (2018a). Data on number of foreigners. https://www.czso.cz/csu/cizinci/ number-of-foreigners-data. Accessed 31 July 2019.

Czech Statistical Office. (2018b). Foreigners: Employment-data. https://www.czso.cz/csu/ cizinci/3-ciz_zamestnanost\#rok. Accessed 31 July 2019.

Czech Statistical Office. (2019). Zaměstnanost a nezaměstnanost podle výsledků VŠPS - 2. čtvrtletí 2019. https://www.czso.cz/csu/czso/cri/zamestnanost-a-nezamestnanost-podle-vysledkuvsps-2-ctvrtleti-2019 (2019). Accessed 7 Aug 2019.

Czech-Moravian Confederation of Trade Unions. (2017). Vzkaz ČMKOS budoucí vládě. https:// www.tripartita.cz/vzkaz-cmkos-budouci-vlade. Accessed 8 Aug 2019.

Drbohlav, D. (2003). Immigration and the Czech Republic (with a Special focus on the foreign labor force). International Migration Review, 37(1), 194-224.

European Migration Network. (2019). Labour market integration of third-country nationals in EU member states (Synthesis Report for the EMN Study). https://ec.europa.eu/home-affairs/sites/ homeaffairs/files/00_eu_labour_market_integration_final_en.pdf. Accessed 8 Aug 2019.

Ford, J. (2016). The risks of regulatory ritualism: Proposals for a treaty on business and human rights (April 2, 2016). Global Economic Governance, Working Paper 118. https://ssrn.com/ abstract $=3206434$. Accessed 8 Aug 2019.

Heimer, C. A., \& Gazley, J. L. (2012). Performing regulation: Transcending regulatory ritualism in HIV clinics. Law \& Society Review, 46(4), 853-887.

Koldinská, K., Sheu, H. C., \& Štefko, M. (2015). Sociální integrace cizinců. Praha: Auditorium.

Kušniráková, T. (2014). Is there an integration policy being formed in Czechia? Identities: Global Studies in Culture and Power, 21(6), 738-754.

Mahoney, J., \& Thelen, K. (2009). Explaining institutional change: Ambiguity, agency, and power. Cambridge: Cambridge University Press.

Meyer, J. W., \& Rowan, B. (1977). Institutionalized organizations: Formal structure as myth and ceremony. American Journal of Sociology, 83(2), 340-363.

Merton, R. K. (1968). Social theory and social structure. New York: Free Press.

Multicultural Centre Prague. (2013). DoporuČení pro nastavení politiky v oblasti zahraniČní zaměstnanosti.https://mkc.cz/doc/Doporuceni_pro_nastaveni_politiky_v_oblasti_zahranicni_ zamestnanosti.pdf. Accessed 8 Aug 2019.

Organization for Aid to Refugees. (2016). Aktuální problémy slučování rodin migranti̊ a právo na soukromý a rodinný život a pripravovaná novela cizineckého zákona. https://www.opu.cz/ wp-content/uploads/2016/06/Slučován\%C3\%AD_rodin_cizinců.pdf. Accessed 8 Aug 2019.

Pachocka, M. (2016). Understanding the Visegrad group states' response to the migrant and refugee crises 2014+ in the European Union. Yearbook of Polish European Studies, 19, 101-132.

Power, M. (1997). The audit society. Oxford/New York: Oxford University Press.

Public Opinion Research Center. (2019). The Czech Public views on foreign nationals. https:// cvvm.soc.cas.cz/en/press-releases/other/relations-attitudes/4904-the-czech-public-s-views-onforeign-nationals-march-2019. Accessed 30 Oct 2019.

Rahimi, F. (2017, March 30). Žádná př́ísnost není na cizince dost velká. Deník Referendum. http:// denikreferendum.cz/clanek/24956-zadna-prisnost-neni-na-cizince-dost-velka. Accessed 8 Aug 2019.

Roberts, J., Stalans, L., Indermaur, D. \& Hough, M. (2003). Penal populism and public opinion. New York: Oxford University Press .

Samier, E. (1997). Administrative ritual and ceremony: Social aesthetics, myth and language use in the rituals of everyday organizational life. Educational Management \& Administration, 25(4), 417-436. 
Svoboda, M. (2015, November 6). Zahraniční pracovníci nesmějí být nástrojem sociálního dumping. Rozhovor Haló novin s předsedou Odborového svazu Stavba Stanislavem Antonivem. Haló noviny. https://www.odbory.info/obsah/5/zahranicni-pracovnici-nesmeji-byt-nastrojemsocialnihodumpi/14236. Accessed 8 Aug 2019.

Zelenka, J., \& Štěpánek, N. (2018, February 26). Cizinců pracujících v Česku načerno přibývá. Firmy hledají zaměstnance a riskují i vysoké pokuty. Hospodářské noviny. https://archiv.ihned. cz/c1-66060730-cizincu-pracujicich-nacerno-pribyva. Accessed 8 Aug 2019.

Open Access This chapter is licensed under the terms of the Creative Commons Attribution 4.0 International License (http://creativecommons.org/licenses/by/4.0/), which permits use, sharing, adaptation, distribution and reproduction in any medium or format, as long as you give appropriate credit to the original author(s) and the source, provide a link to the Creative Commons license and indicate if changes were made.

The images or other third party material in this chapter are included in the chapter's Creative Commons license, unless indicated otherwise in a credit line to the material. If material is not included in the chapter's Creative Commons license and your intended use is not permitted by statutory regulation or exceeds the permitted use, you will need to obtain permission directly from the copyright holder.

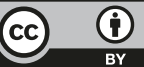

